\title{
Pedagógusnézetek megismerésének lehetőségei a kétnyelvi pedagógusképzés és továbbképzés kontextusában ${ }^{1}$
}

\author{
Trentinné Benkő Éva \\ Eötvös Loránd Tudományegyetem Tanító- és Óvóképző Kar, Budapest
}

\begin{abstract}
A pedagógusképzés célja és feladata a laikus pedagógiai vélekedések, nézetek (beliefs) feltárása, ütköztetése és szükség szerint megváltoztatása. A cikk először a szakirodalmi hátteret vázolja fel a nézetek fogalmának tisztázására és pedagógusképzésben betöltött szerepükre vonatkozóan. Ezután néhány, a nézetek felszínre hozására alkalmas technikát és módszert mutat be a kétnyelvi pedagógusképzés kontextusában. Végezetül egy technika és eszköz (metaforarács) részletesebb ismertetésére kerül sor.
\end{abstract}

Kulcsszavak: nézetek (laikus pedagógiai vélekedések), kvalitatív technikák, metaforák pedagógiai alkalmazása, metaforarács, kétnyelvi pedagógusképzés

\section{Bevezetés}

A laikus pedagógiai vélekedések, nézetek (beliefs) megismerése a pedagógusképzés és továbbképzés egyik legfontosabb célja és feladata. Az utóbbi évtizedek hazai pedagógiai kutatásaiban egyre nagyobb szerep jut újszerü kvalitatív technikák alkalmazásának, a nézetek feltárása és ezáltal a képzés hatékonyabbá tétele érdekében. Az elméleti megalapozást követően bemutatásra kerül, hogy milyen módszerek, eszközök és eljárások alkalmazhatók a kétnyelvi pedagógusképzés kontextusában a nézetek megismerésére. Az egyes technikák segítségével tudatosíthatók a kétnyelvüséggel és a korai intézményes kétnyelvű fejlesztéssel, a kétnyelvi pedagógus feladataival, kihívásaival és szükséges kompetenciáival kapcsolatos személyes pedagógiai filozófiák, egyéni vélekedések.

\section{Szakirodalmi háttér}

Az utóbbi évtizedek pedagóguskutatásaiban a gondolkodást középpontba állító irányzatok kerültek előtérbe. Újfajta megközelítés és metodika vált szükségessé, amelynek során a pedagógiai gondolkodás és döntéshozás mélyebb megismerését, megértését segítő új típusú módszerek, technikák alakultak ki. Míg a reflektív gondolkodás kutatásának módszerei közé sorolható például a hangosan gondolkodás, a támogatott felidézés, valamint a narratív módszerek, addig a tanári hitek-nézetek-előfeltevések (beliefs) feltárására alkalmas módszerek közé tartozik többek között a fogalmi térkép és a metaforaalkotás (vö. Vámos, 2001ab, 2003ab; Szabolcs, 1999, 2001; Szivák, 2002, 2003ab; Dudás, 2005, 2007).

A szakirodalom eltérő tartalommal ruházza fel a nézeteket attól függően, hogy egyes kutatók mennyire tekintik ezeket elméleti jellegűnek és mennyire konkrét, ké-

\footnotetext{
${ }^{1}$ A cikkben a kétnyelvi és kétnyelvű fogalmakat eltérő értelemben használom. A kétnyelvű kifejezést a kétnyelvű (azaz két nyelven zajló) nevelési-oktatási folyamatokra, programokra; amíg a kétnyelvit az abban részt vevő (nem okvetlenül kétnyelvű) pedagógusokra és a kétnyelvi (nem két nyelven, hanem kizárólag egy, azaz a célnyelven folyó) képzésre és az abban tanuló hallgatókra alkalmazom.
} 
Pedagógusnézetek megismerésének lehetőségei a kétnyelvi pedagógusképzés és továbbképzés kontextusában

pekben kifejeződő, szemléletes képződményeknek (Wubbels, 1992; Korthagen, 1993). Fontos szempont továbbá, hogyan különböztetik meg a nézeteket a hasonló konstrukcióktól, a tudástól és az attitűdöktől (Calderhead, 1996. 719. o.; Dudás, 2006). Míg az attitűdök inkább affektív, addig a nézetek inkább kognitív jellegü pszichikai képződmények (Kimmel, 2007. 15. o.). A konstruktivista felfogás nem különíti el a tudást a nézetektől (Kimmel, 2007). Eszerint a tudás is egyfajta szubjektív meggyőződés, személyes konstrukció eredménye, hasonlóan a nézetekhez, melyek olyan feltételezések, propozíciók a világról, amelyeket igaznak vélünk (Richardson, 1996. 103. o.). Ugyanakkor mindkettő nehezen változtatható, és döntően befolyásolja az egyén döntéseit és tetteit, mert szürőként, filterként, értelmezési lencseként működik (Richardson, 1996. 103. o.; Falus, 2001. 23. o.). A nézetek olyan szubjektív elméletek, amelyek egy adott területre, jelenségre vonatkozó értékek és eszmék integráns egységét jelentik, és ezáltal segítik az egyént saját személyiségének és a világnak a megértésében (Polak, 1998 in Falus, 2006. 30-31. o.). Tapasztalatokból, élményekből származó mentális konstrukciók, amelyek döntően befolyásolják ítéleteinket és mások megítélését is (Richardson, 1996. 103. o.; Dudás, 2007. 48. o.). A nézetek többnyire implicitek, kívül esnek a tudatosság határán, elemzés és reflektálás nélküli folyamatban jönnek létre. Falus (1998, 2001, 2002, 2007); Hunyadyné (2001, 2004, 2006); M. Nádasi (1999, 2001, 2002, 2006) és Dudás (2005, 2007), Bárdossy és Dudás (2011) több publikációban tárja fel és összegzi a pedagógusok, pedagógusjelöltek nézeteivel és azok változásával kapcsolatos hazai és külföldi vizsgálatokat. $A$ hivatkozott kutatók szerint a pedagógusképzés egyik legfontosabb célja a jelöltek szürőként viselkedő laikus nézeteinek összhangba hozása a korszerű ismeretekkel. Feladata a nem mindig fogalmi szinten levő, rejtett nézetek feltárása, felhasználása, a képzés tartalmának megfelelő didaktika-elmélettel való szembesítése és ha szükséges, megváltoztatása. Olyan kognitív disszonancia létrehozása, ami motiválja a jelöltet a tanulásra, saját mentális modelljének átalakítására az új ismereteknek megfelelően. Ezt a pedagógusképzés úgy érheti el, ha olyan élményszerü megtapasztalást tesz lehetővé, amely elősegíti, hogy a jelölt érzékelje a sajátjától eltérő valóságkonstrukciót, ami előidézi a konceptuális váltást. Kiemelik továbbá, hogy a pedagógusjelöltek szakmai fejlődésének egyik legfontosabb állomása az implicit nézetek explicitté alakítása.

A tanárok nézetrendszere különösen jól vizsgálható kvalitatív módszerekkel, hiszen legtöbbször nem tudatosan reflektált, hanem képekben és élményekben rögzülő konstrukciókról van szó. A pedagóguskutatás terén az elmúlt években, hazánkban is egyre népszerübbé vált a kvalitatív kutatási metodológia alkalmazása (a teljesség igénye nélkül: Szabolcs, 1999, 2001; Golnhofer, 2001; Ehmann, 2002; Szivák, 2002; Seidman, 2002; Nahalka, 2003; Sántha, 2004, 2006). A pedagógiai nézetek megismerésére és tudatosítására alkalmas hagyományos feltáró módszerek közé tartozik a megfigyelés, az interjú és a kérdőív. Új generációs módszerek és technikák is meghonosodtak a hazai és külföldi pedagógiai nézetkutatásokban, mint például a fogalmi térkép, a metafora és a mesealkotás, valamint a számítógépes tartalomelemzés, amelyek különösen alkalmasnak bizonyultak a nézetek feltárására. Többek között ezen kvalitatív kutatási módszerek és technikák alkalmazásáról számol be részletesen Szabolcs (1999, 2001); Szivák (2002, 2003); Ehmann (2002); és Vámos (2001ab, 2003ab, 2008). Hunyadyné és Ungárné (1999) eredetileg a pályaalkalmasság felmérésére egy olyan innovatív eljárást alkalmazott, amely szépirodalmi szemelvények elemzésével, a szereplők értékelésével támogatta a pedagógiai nézetek feltárását (Hunyadyné, 2004). A hallgatói nézetek, tanári vélekedések megismerése érdekében számos újszerü módszert alkalmaznak a pedagógusképzésben. Ilyen többek között a szakirodalmi szövegek feldolgozására alkalmazott „kettéosztott papír” vagy „az utolsó szó jogán" technikák (Dudás, 2007; Bárdossy és Dudás, 2011), amikor a hallgatók a jelentésteremtési folyamatban felhasználják már meglévő ismereteiket és kognitív sémáikat. 
Wubbels (1992) feltételezése szerint a hallgatói nézetek, prekoncepciók egy világképet alkotnak, amelyek szimbólumokkal írhatók le és úgynevezett jobbagyféltekestratégiákkal tárhatók fel és befolyásolhatók. Dudás (2007. 53. o.) szerint „a tapasztalatok nyomán kialakult nézetek, elkötelezettségek, vélekedések a pedagógusok, hallgatók gondolkodásának mélyén húzódnak meg. Elemeik képekben, élményekben rögzülnek, a fogalmi gondolkodás számára nehezen hozzáférhetők, nem mindig fejezhetők ki verbálisan". A nézetek megismerésének mindezek alapján hatékony módja lehet a metaforavizsgálat (Golnhofer és Nahalka, 2001; Vámos, 2001ab, 2003ab; Trentinné, 2008, 2013ab, 2016) és a mese pedagógiai célú alkalmazása (Vámos, 2008; Trentinné, 2014). A metaforákat a pedagógiában itthon elsőként az ELTE Neveléstudományi Intézetének kutatói alkalmazták (Golnhofer és Nahalka, 2001; Réthy, 2001; Vámos, 2001ab, 2002, 2003ab; Szivák, 2003). „A tudományos kutatásban azért élénkült meg a metaforavizsgálat iránti érdeklődés, mert rávilágíthat a tudatunkban zajló, az énkontroll miatt nehezen megközelíthető belső világra", állítja Vámos Ágnes (2003a, 28. o.). A metaforavizsgálat keretében jelentéskapcsolatot keresünk „a jelentés szempontjából látszólag nem összekapcsolódó entitások között”, hogy bonyolult fogalmainkat könnyebben megérthessük a „hozzájuk füződő konkrét képzetek segítségével” (Vámos, 2003a. 22-23. o.). Lakoff és Johnson (2003) bebizonyította, hogy a hagyományos felfogással szemben a metafora a fogalmak jellemző tulajdonsága (nem a szavaké), funkciója nem csupán múvészi vagy esztétikai, hanem az is, hogy segítse bizonyos fogalmak megértését. A metaforák alapja gyakran nem a hasonlóság, továbbá, azokat köznapi emberek is használhatják minden nehézség nélkül (nincs szükség különleges tehetségre), és nemcsak nyelvi díszítőeszköz, hanem az emberi gondolkodás és megértés elengedhetetlen kelléke (vö. Kövecses, 2005). A metaforavizsgálatok lényege - mint minden kvalitatív kutatásé - az, hogy egyéni leírást, jellemzést adjon a vizsgálat tárgyát képező különböző jelenségekről, fogalmakról, személyekről, pedagógiai szituációkról; minden esetben a belső, rejtett motívumok, nézetek és gondolkodásmód feltárása és megértése a cél (Sántha, 2006; Szivák, 2002; Szabolcs, 2001). A metaforavizsgálaton kívül ugyanakkor számos egyéb lehetőség is nyílik a pedagógiai vélekedések megismerésére.

\section{A pedagógiai nézetek megismerésére alkalmazott néhány eljárás}

A kétnyelvű oktatási-nevelési feladatok ellátására felkészítő képzés/továbbképzés során általam alkalmazott leggyakoribb nézetfeltáró technikák az 1 . számú táblázatban kerültek összesítésre. A megnevezett - pedagógiai vélekedések megismerésére és ütköztetésére alkalmas - módszerek és eljárások közül a terjedelmi korlátok miatt csak néhányat ismertetek az alábbiakban.

\begin{tabular}{|c|c|c|}
\hline \multirow{7}{*}{ 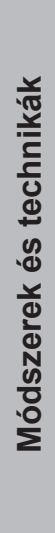 } & \multicolumn{2}{|c|}{ Nézőpontok, célközönség } \\
\hline & Munka világa (gyakorló pedagógusok) & Pedagógushallgatók \\
\hline & $\begin{array}{l}\text { Elővizsgálat: szóbeli és írásbeli kikérdezés; } \\
\text { Kérdőíves kikérdezés }\end{array}$ & $\begin{array}{l}\text { Kérdőíves kikérdezés nyitott kérdések } \\
\text { alapján }\end{array}$ \\
\hline & Metaforavizsgálat (kétféle technikával) & Metaforavizsgálat (kétféle technikával) \\
\hline & Meseelemzés & $\begin{array}{l}\text { Meseelemzés, írásos és szóbeli hallgatói } \\
\text { reflexiók, naplózás }\end{array}$ \\
\hline & $\begin{array}{l}\text { Vizuális megjelenítések és szöveges kreatív } \\
\text { alkotások (pl. recept, társasjáték) }\end{array}$ & $\begin{array}{l}\text { Vizuális megjelenítések és részben } \\
\text { szöveges kreatív alkotások, írásos és } \\
\text { szóbeli hallgatói reflexió, naplózás }\end{array}$ \\
\hline & $\begin{array}{l}\text { Egyéb projektív technikák: } \\
\text { mondatbefejezés, } \\
\text { szimulációk (videóra rögzítve) }\end{array}$ & $\begin{array}{l}\text { Reflexiós fogalmazások elemzése: a } \\
\text { kétnyelvi szakmai gyakorlatról, önfejlődési } \\
\text { beszámolók és a képzésről }\end{array}$ \\
\hline
\end{tabular}

1. táblázat: Az alkalmazott módszerek és technikák a nézetek feltárására (2007-2016) 
Pedagógusnézetek megismerésének lehetőségei a kétnyelvi pedagógusképzés és továbbképzés kontextusában

Elsőként a kooperatív csoportokban megvalósítható szimulációkra és projektekre vonatkozóan szerepeltetek különböző tevékenységeket. A 2. táblázat olyan feladatleírásokat tartalmaz, amelyek szituációikban és fókuszukat tekintve alkalmasak a résztvevők (jellemzően gyakorló pedagógusok) személyes pedagógiai filozófiáinak feltárására az intézményes kétnyelvű fejlesztés témakörében. A feladatok megoldása, megbeszélése, a szimulációs helyzetekre való felkészülés kooperatív munkaformákban, föként csoportokban, esetenként párban történik. A szimulációs helyzeteket, szerepjátékokat videóra rögzítve és közösen visszanézve különösen alkalmasak az implicit nézetek explicitté változtatására.

Szimulációs helyzetek és projektfeladatok

1. A kétnyelvi pedagógus munkaköri leírásának megalkotása, amely tartalmazza az összes ellátandó feladatot, a tananyagfejlesztéstől a szülökkel való kapcsolattartáson át a külföldi partnerintézményekkel való levelezésig - intézményi és munkaközösség-vezetőként.

2. Az adott intézménybe meghirdetett kétnyelvi pedagógusi állásra pályázók közül a legalkalmasabb jelentkező kiválasztása indoklással rövid, tömör szakmai önéletrajzok alapján (a képzés vezetője biztosítja vagy ők írják azokat) - munkaközösség-vezetőként.

3. A tökéletes, lehetőség szerint minden fontos szempontot figyelembe vevő, ugyanakkor a realitás talaján maradó, „hihető” szakmai önéletrajz megírása - állást kereső kétnyelvi pedagógusként.

4. Egy, a munka világából nézve minden fontos feladatra, kihívásra megfelelően felkészítő kétnyelvipedagógus-képzési/továbbképzési modul kidolgozása: a tantárgyakkal, tematikával, elmélet és gyakorlat arányával stb. - kétnyelvi szakértői munkacsoport tagjaként.

5. Panelbeszélgetés, szakmai kerekasztal a kétnyelvű oktatás-nevelés előnyeiről és esetleges hátrányairól, a résztvevőket ellenzők és támogatók táborára osztva - intézményvezetőként, pedagógusként (kétnyelvi és nem kétnyelvi, pl. magyaros), kutatóként, egyetemi oktatóként, minisztériumi döntéshozóként.

6. Tipikus mindennapi szituáció: Szülök beszélgetnek a játszótéren, a gyereküknek jó óvodát, iskolát keresnek, és természetesen szóba kerülnek a különböző (állami, alapítványi, külföldi, magán...) kétnyelvű - két tanítási nyelvü intézmények. Parázs vita alakul ki. Előbb-utóbb elkerülhetetlen, hogy Te is állást foglalj - szülőként és gyakorló kétnyelvi pedagógusként.

7. Új - a kétnyelvű tanításban-nevelésben kezdő - kolléga érkezik az intézményedbe, és Te kapod a „mentorálási” feladatot, hogy segítsd őt a beilleszkedésben, a napi munkavégzésben. Fogalmazz meg minél több hasznos, gyakorlati tanácsot, hogy mit tegyen és mit ne! - tapasztalt pedagógusként, mentorként.

8. A kétnyelvű oktatást be akarják szüntetni az intézményben, ahol dolgozol, vagy ahova a gyermeked jár. Lépj fel támogatóként, szólalj fel a kétnyelvű program megőrzése érdekében a szülői fórumon (míg mások, pl. minisztériumi döntéshozók, ellenzőként védik majd a beszüntetés ötletét). Érvelj és vitázz - érintett szülőként, pedagógusként.

9. Szülői értekezlet, fogadóóra keretében egyes szülők arról panaszkodnak, hogy nem érzékelik (óvodás, kisiskolás) gyermekük nyelvi előrehaladását, hiszen az pl. nem képes tolmácsolni, telefonon beszélni az üzleti partnereikkel stb. Magyarázd el a szülőknek a korai nyelvi fejlesztés céljait és feladatait - a gyermekeiket tanító, fejlesztő nyelvpedagógusként.

\section{2. táblázat: Szimulációs helyzetek a pedagógusnézetek feltárására}

Az egyéni feladatként megoldandó, a személyes filozófiák, nézetek feltárására kimondottan alkalmas tevékenységek közül kiemelkedik a gondolati térkép, a metaforaalkotás és a mese pedagógiai alkalmazása. A hallgatói portfólióknak fontos részét képezik a saját önfejlődéssel kapcsolatos, a gyakorlat során tapasztaltakra reflektáló írások mellett a következő feladatok. Az alább felsorolt négy elem (A-D) és a hozzájuk kapcsolódó írásos reflexiók, valamint szóbeli bemutatásuk nemcsak a nézetek megismerésére, hanem az egyes jelöltek aktuálisan elért tanulási eredményeinek megítélésére is alkalmas (lásd még Trentinné, 2013ab, 2014, 2015ab). 
A) Készítse el a kurzus témájához szervesen kapcsolódó gondolati térképet (pl: kétnyelvüség, korai kétnyelvü fejlesztés, az intézményes korai kétnyelvüség központi elemmel)!

B) Ábrázolja vizuálisan az ideális kétnyelvi pedagógust egy tetszőleges, szabadon választható technika alkalmazásával!

C) Írjon egy mesét a kezdő kétnyelvi pedagógus viszontagságairól és győzedelmeskedéseiről!2

D) Készítsen egy társasjátékot az ideális kétnyelvi pedagógussá válás folyamatáról!

Az egyéni pedagógiai vélekedések, laikus nézetek megismerésének egyik meghatározó módszere a metaforavizsgálat. A következőkben ennek bemutatására térek át részletesebben.

\section{Metaforaalkotás az egyéni hallgatói nézetek megismerésére}

Kétféle metaforagyűjtési technikát használok a gyakorló pedagógusok és a hallgatók nézeteinek jobb megismerése érdekében. Az egyik megközelítés a hazai metaforavizsgálatokban gyakran használt, immár hagyományosnak számító hasonlat technika (kérdőíves kikérdezéssel, mondatbefejezéssel ${ }^{3}$; vö. Vámos, 2003a. 42. o.), míg a másik egy itthon kevéssé elterjedt, újszerü eszköz, a metaforarács alkalmazása. Mindkét esetben oktatói kérésre a résztvevők által önállóan megfogalmazott, nem provokált metaforák születtek (vö. Vámos, 2003a. 36. o., 2003b). A hasonlat technikával a metaforák begyüjtése időnként nehézkesnek bizonyult és rendszeresen igényelt szóbeli magyarázatot, oktatói segítséget és biztatást. A metaforaalkotási folyamat megkönnyítésére egy nagyszámú metaforát inspiráló rácsot alkalmaztam (lásd az 1. mellékletben), a föként piackutatásban használt brand personification (márka-megszemélyesítés) technika alapján. A metaforarácsot több szempontból is hatékony eszköznek tartom a szakirodalomban ismertetett más metaforagyűjtési technikákkal összehasonlítva (vö. Vámos, 2013b). Önálló metaforákat inspirál szemben a listás választással és az ágrajzzal. Nem behatároló és korlátozó, valamint nem igényel külön magyarázatot, sem előzetes felkészítést, mint a táblázat analógiával technika. Ugyanakkor, kategóriával és táblázatos formájával megkönnyíti a feladat megértését és a metaforaalkotási folyamatot. A megjelenített több „lehetőség" nemcsak vizuálisan sugall gyorsabb és egyszerübb feladatmegoldást, hanem biztosítja a kategóriák közüli szabad választás lehetőségét is.

A válaszadókat egy 10 általános kategóriát (többek között növény, állat, természeti jelenség, jármű, híres ember) tartalmazó táblázat kitöltésére kértem. Az instrukció a következő kérdést tartalmazta: „Mi vagy ki lenne az ideális kétnyelvi pedagógus, ha ... lenne?” A résztvevőknek az adott hívószó, a megnevezett gyüjtőfogalom alapján kellett egy-egy példát, lehetőség szerint az első asszociációikat leírni indoklással együtt. A foglalkozás kategóriát tudatos döntés alapján nem szerepeltettem a táblázatban. Egyrészt, a pedagógiai szakirodalomban már számos esetben szerepelt a tanár célfogalomra foglalkozásmetafora alkalmazása (lásd például az állatidomár, rendező, színész, kertész, szobrász vagy éppen állatszelidítő vagy börtönőr metaforák, Vámos, 2001ab, 2002, 2003ab; Bullough és Stokes, 1994; Pittman és O’Neill, 2001; Ben, Peretz, Mendelson és Kron, 2003). Másrészt,

\footnotetext{
2 Egy hallgatói mese és a hozzá tartozó reflexió olvasható a 2. sz. mellékletben.

3 Fejezze be a következő mondatot egy hasonlattal! Az ideális/hatékony/sikeres kétnyelvi pedagógus olyan mint $\mathrm{a}(\mathrm{z}) \ldots$ mert ... (A feladat utasítása mellett egy példamondat is szerepelt a témához nem kapcsolodó célfogalommal kapcsolatban.)
} 
Pedagógusnézetek megismerésének lehetőségei a kétnyelvi pedagógusképzés és továbbképzés kontextusában

a kétnyelvi gyakorló pedagógusok által alkotott metaforák és forrástartományai között is szerepelt számos foglalkozásmegnevezés a polihisztortól a nagyköveten, a szuperhősön és a kettős ügynökön át egészen a varázslóig (Trentinné, 2008, 2009, 2013a).

A metaforarács technikával begyűjtött metaforák és indoklásaik egyaránt információt szolgáltatnak az adott hallgató vagy pedagógus nézeteiröl. Míg a metaforák a rejtett nézetekbe engednek bepillantást, addig az indoklások az aktuálisan elért tanulási eredményekről is tanúskodnak. Ez megfigyelhető az egyre tudatosabban megjelenő nézetek és a pedagógiai szaknyelv egyre következetesebb alkalmazása kapcsán is. $A$ nézetek kialakulását, megszilárdulását jelzi az a tény is, hogy a hallgatók magyarázataikban sokszor nyelvi eszközökkel is alátámasztják véleményüket, amely konkrétan a célfogalomra, a kétnyelvi pedagógusra vonatkozik, és nem kizárólag az általuk alkotott metaforát értelmezi. Sokan a kijelentő módú megfogalmazást választják vagy a még határozottabb elköteleződést jelző felszólító módot alkalmazzák (legyen, tudjon, legyen képes). A megfogalmazások megfeleltethetők az egyes stúdiumok, a kétnyelvi képzési program követelményszintjeinek, illetve az elvárható tanulási eredményeknek (LeO, vö. Allan, 1996; Adam, 2004; Vámos, 2011).

A pedagógusképzés során a cél a hallgatói nézetek feltárása, megértése, és szükség esetén megváltoztatása. Az oktatónak arra is gondot kell fordítania, hogy az általa feltárt nézetek ütköztetésére, a felmerült kérdések, problémák, aggodalmak feldolgozására is megteremtse a lehetőséget az egyes hallgatókkal vagy hallgatói csoportokkal megbeszélés, konzultáció, élményszerü tanítás, reflexió, projektmunka során, illetve más módon. A 3. számú táblázatban bemutatott metaforarács-részletben az idézett elsőéves hallgató indoklásai alkalmasak a kétnyelvűséggel, a kétnyelvű fejlesztéssel kapcsolatos hitek és tévhitek, kételyek és ellenérvek egyéni vagy csoportos átbeszélésére a válaszadó anonimitásának megőrzésével.

\begin{tabular}{|c|c|c|}
\hline $\begin{array}{l}\text { Hallgató által alkotott } \\
\text { METAFORA } \\
\text { (kategória) }\end{array}$ & $\begin{array}{l}\text { A metafora hallgató általi indoklása } \\
\text { (szószerinti idézet) }\end{array}$ & $\begin{array}{l}\text { Oktatói megállapítás } \\
\text { (TBÉ) }\end{array}$ \\
\hline $\begin{array}{l}\text { TÖKFŐZELÉK } \\
\text { (Étel) }\end{array}$ & $\begin{array}{l}\text { Vannak, akik nem szeretik, de van, aki elismeri } \\
\text { a fontosságát. }\end{array}$ & \multirow{5}{*}{$\begin{array}{l}\text { Kételyek } \\
\text { fogalmazódnak } \\
\text { meg a korai } \\
\text { kétnyelvü fejlesztés } \\
\text { társadalmi-szakmai } \\
\text { elfogadottsága } \\
\text { kapcsán. }\end{array}$} \\
\hline $\begin{array}{l}\text { SIGHT-SEEING BUSZ } \\
\text { (Jármű) }\end{array}$ & $\begin{array}{l}\text { Bárki úgy dönthet, hogy kipróbálja, és le is } \\
\text { szállhat, ha nem tetszik a látvány. }\end{array}$ & \\
\hline $\begin{array}{l}\text { EIFFEL-TORONY } \\
\text { (Épület/építmény) }\end{array}$ & $\begin{array}{l}\text { Mindenki tud róla (hogy szép és jó), de } \\
\text { csak tervezgetik, hogy érdemes lenne } \\
\text { megtapasztalni. }\end{array}$ & \\
\hline $\begin{array}{l}\text { MICIMACKÓBÓL A } \\
\text { NYUSZI (Meseszereplő) }\end{array}$ & $\begin{array}{l}\text { Sokakat idegesít, de aki megérti, az elfogadja, } \\
\text { szereti. }\end{array}$ & \\
\hline $\begin{array}{l}\mathrm{DA} \text { VINCl } \\
\text { (Híres ember) }\end{array}$ & Neki is meg kellett küzdenie az antipátiával. & \\
\hline
\end{tabular}

3. táblázat: Egy elsőéves kétnyelvi képzésben részt vevő hallgató metaforarács-részlete

\section{Egy adott hallgató nézetrendszerének feltárása a metaforarács segítségével}

Egy nappali tagozatos elsőéves hallgató (ND) teljes metaforarácsát mutatom be a következőkben. A 4. táblázatban egy nézetrendszer bontakozik ki a metaforák és magyarázataik segítségével számos releváns témakörben:

\footnotetext{
${ }^{4}$ A megnevezett metaforákat nagy betűvel szedve jelölöm (Kövecses, 1998), az egyéb nyelvi elemek, az indoklások kiemelésére a dőlt betűs szedést alkalmazom.
} 
- A jó kétnyelvi pedagógus kompetenciái

- A kétnyelvi pedagógus szakmai profilja

- A kétnyelvi pedagógus feladata

- A korai kétnyelvü fejlesztés céljai és folyamata

- A korai kétnyelvű fejlesztés módszerei

\begin{tabular}{|c|c|c|}
\hline $\begin{array}{l}\text { Hallgató } \\
\text { által alkotott } \\
\text { METAFORA } \\
\text { (kategória) }\end{array}$ & $\begin{array}{c}\text { A metafora hallgató általi } \\
\text { indoklása (szószerinti } \\
\text { idézetek) }\end{array}$ & Oktatói megjegyzések, gondolatok (TBÉ) \\
\hline $\begin{array}{l}\text { BOROSTYÁN } \\
\text { (növény) }\end{array}$ & $\begin{array}{l}\text { Ahogy a növény növekszik, úgy } \\
\text { gyarapitja az óvodapedagógus } \\
\text { is a gyerek tudását; fejlödnek. }\end{array}$ & $\begin{array}{l}\text { Természetes folyamat: fejlődés-fejlesztés, } \\
\text { nyelvelsajátítás. Érdemes lenne feltárni, } \\
\text { hogy a nevelő és a gyeremek együtt } \\
\text { fejlődésére gondol-e. }\end{array}$ \\
\hline $\begin{array}{l}\text { ÉNEKES MADÁR } \\
\text { (állat) }\end{array}$ & $\begin{array}{l}\text { Az újdonság erejével hat. Eltér } \\
\text { a szokványostól. Kellemes, } \\
\text { játékos tanulás. }\end{array}$ & $\begin{array}{l}\text { A korai kétnyelvű fejlesztés a hallgató } \\
\text { laikus pedagógiai vélekedése szerint ma } \\
\text { Magyarországon még mindig újdonságnak, } \\
\text { számít. Fontos eleme a játékosság! }\end{array}$ \\
\hline $\begin{array}{l}\text { SZIVÁRVÁNY } \\
\text { (természeti } \\
\text { jelenség) }\end{array}$ & $\begin{array}{l}\text { A nyelvek sokszínüségét } \\
\text { ismerhetik meg a gyerekek, } \\
\text { eljutnak valamilyen szintröl egy } \\
\text { magasabb szintre. }\end{array}$ & $\begin{array}{l}\text { A nyelvi sokszínűség gondolata jelenik } \\
\text { meg, fontos a megismerés, a fejlődés mint } \\
\text { folyamat (nem a cél) a középpontban, } \\
\text { megjelenik a fejlődési szintek gondolata. }\end{array}$ \\
\hline $\begin{array}{l}\text { MAJORANNÁS } \\
\text { HÚS RIZZSEL } \\
\text { (étel) }\end{array}$ & $\begin{array}{l}\text { A rizsszemek az új szavak, } \\
\text { kifejezések, a szósz maga a } \\
\text { folyamat, amely összetartja } \\
\text { a játékos tanulást az } \\
\text { óvodapedagógus előadásában. }\end{array}$ & $\begin{array}{l}\text { Komplex és jó dolognak tekinti a kétnyelvü } \\
\text { fejlesztést, amit sok összetevő együttesen } \\
\text { tesz teljessé. Minden összetevőnek megvan } \\
\text { a fontos szerepe. A játék, a tanulás, mint } \\
\text { színházi előadás jelenik meg, amelyben az } \\
\text { óvodapedagógus a főszereplő. }\end{array}$ \\
\hline $\begin{array}{l}\text { BUBORÉKOS } \\
\text { ÁSVÁNYVÍZ } \\
\text { (innivaló) }\end{array}$ & $\begin{array}{l}\text { Felpezsdít, új távlatokat nyit. } \\
\text { Valami ismeretlenbe vezet, és } \\
\text { tanít. A felszínre hozza a tudást } \\
\text { és a sikert. }\end{array}$ & $\begin{array}{l}\text { Érdekes, izgalmas kihívást jelent a tanulási } \\
\text { folyamat, a pedagógus feladata a motiváció, } \\
\text { az érdeklődés felébresztése, fenntartása, } \\
\text { a tudás felszínre hozása, a sikerélmény } \\
\text { biztosítása. }\end{array}$ \\
\hline $\begin{array}{l}\text { REPÜLŐGÉP } \\
\text { (jármű) }\end{array}$ & $\begin{array}{l}\text { Rengetegen „igénybe” vehetik, } \\
\text { és olyan távlatokig el lehet } \\
\text { jutni, ahonnan másik „,jármüvel” } \\
\text { tovább lehet haladni (tanulási } \\
\text { folyamat, szintek). }\end{array}$ & $\begin{array}{l}\text { Nem elitképzésként gondol a kétnyelvű } \\
\text { fejlesztésre, ami nemcsak a legjobbak } \\
\text { kiváltsága, hanem mindenki számára } \\
\text { elérhető távlatként. Előrevetíti a } \\
\text { segítségével elérhető eredményeket, a } \\
\text { sikeres iskolai nyelvtanulást. Megjelennek a } \\
\text { „Szintek” a tanulási folyamatban. }\end{array}$ \\
\hline $\begin{array}{l}\text { VARÁZSLÓ } \\
\text { (meseszereplő) }\end{array}$ & $\begin{array}{l}\text { Sok újdonságot és } \\
\text { érdekességet hoz a gyermekek } \\
\text { számára (angol játékok). }\end{array}$ & $\begin{array}{l}\text { Érdekes, hogy nem a varázslatot, a csodát } \\
\text { emeli ki a varázsló metafora kapcsán, } \\
\text { hanem az új, érdekes tevékenységeket, az } \\
\text { angol nyelvű játékokat. }\end{array}$ \\
\hline $\begin{array}{l}\text { FELHŐKARCOLÓ } \\
\text { LIFTJE } \\
\text { (épület, építmény) }\end{array}$ & $\begin{array}{l}\text { A tanulás folyamán magasabb } \\
\text { szintekre jutnak el a gyerekek. } \\
\text { Az óvodapedagógus a lift, aki } \\
\text { mindebben segíti őket. }\end{array}$ & $\begin{array}{l}\text { A gyerekek egy fejlődési folyamat során } \\
\text { haladnak folyamatosan előre (itt felfelé). } \\
\text { Az óvodapedagógus feladata az egyre } \\
\text { feljebb juttatás. Itt is megjelenik a „szintek” } \\
\text { kifejezés és a felfelé irányulás (mint a } \\
\text { repülö, a buborékos ásványvíz kapcsán is). }\end{array}$ \\
\hline $\begin{array}{l}\text { ÖRÖKMOZGÓ } \\
\text { (használati tárgy) }\end{array}$ & $\begin{array}{l}\text { Lendületes, új fordulatokra } \\
\text { képes, lenyügöző. }\end{array}$ & $\begin{array}{l}\text { Kitartó, csodálatra méltó, megújuló } \\
\text { energiákkal rendelkezik, aktív, rugalmas, } \\
\text { LLL (Life Long Learning) képessége - a jó } \\
\text { kétnyelvi óvodapedagógus jellemzői. }\end{array}$ \\
\hline $\begin{array}{l}\text { CHUCK NORRIS } \\
\text { (híres ember) }\end{array}$ & $\begin{array}{l}\text { Egy jó óvodapedagógus a } \\
\text { gyermek szemében mindenre } \\
\text { képes. }\end{array}$ & $\begin{array}{l}\text { Chuck Norris kifejezetten jó példa, mert a } \\
\text { kortárs angolszász humorban ő testesíti meg, } \\
\text { hogy valaki mindenre (még a teljes képtelen- } \\
\text { ségekre is) képes. Számos weboldalon talál- } \\
\text { hatók evvel kapcsolatos viccek és mémek. }\end{array}$ \\
\hline
\end{tabular}

4. táblázat: Egy elsőéves hallgató (ND) metaforarácsa és abban megmutatkozó nézetrendszere 
Pedagógusnézetek megismerésének lehetőségei a kétnyelvi pedagógusképzés és továbbképzés kontextusában

A hallgatónál a korai nyelvtanulás mint a nyelvek sokszínűségével való természetes ismerkedés jelenik meg a személyiségfejlesztés folyamatába integrálva. Sokszor használja a „játékos tanulás” kifejezést, amely ebben az esetben a természetes nyelvelsajátítással és annak támogatásával, elősegítésével szinonim kifejezés, hiszen a metaforákból és azok indoklásából egyértelműen megállapítható, hogy nem az iskolai jellegü tudatos tanulásra-tanításra gondol (acquistion vs. learning). Az általa körülírt folyamat egy kellemes, érdekes, változatos, sikert és élményt nyújtó, élvezetes angol nyelvű játéktevékenység, egy természetes, felfelé törő, új távlatokat kínáló, személyiségfejlesztő közös utazás a nyelvek világába a pedagógus vezetésével. A fejlődés folyamat jellege nagy jelentőséggel bír a jelölt számára, többször is előfordul ez a kifejezés az indoklásokban. Ezzel egyidejűleg kiemelt szerep jut a leírásokban a különböző, egymást követő fejlödési szinteknek, feltehetően a tanulmányai során megismert elméleteknek (is) köszönhetően. Nézetrendszerében ezek a szintek egymás felett, egyre magasabban helyezkednek el, erre utal 4 különböző metaforájának indoklásában is (szivárvány, buborékos ásványvíz, repülőgép, felhőkarcoló liftje). $A z$ óvodapedagógus feladata a fejlődési folyamatban a következő szint elérésének segítése. Motiváló, irányító, vezető feladatot lát el, kétséget kizáróan övé a főszerep, amely nem meglepő a 3-5 éves korosztály nevelése esetében. A sikeres kétnyelvi óvópedagógus személyiségvonásai közé tartozik a lendületesség, a változatosság, a sokszínűség csakúgy, mint a kitartás, az energikusság, játékosság és a kreativitás. Egyik legfontosabb jellemzője, hogy a gyerekek szemében mindenre képes, amit jól megtestesít Chuck Norris figurája a mai kortárs angolszász humorban, illetve a Varázsló figurája a mesék világában.

\section{Összegzés}

A cikkben bemutatott technikák, többek között a szimulációs szerepjátékok, a metafora- és mesealkotás alkalmasak a pedagógusnézetek megismerésére számos területen. Segítségükkel következtethetünk a kollégák és pedagógusjelöltek vélekedéseire a korai kétnyelvű fejlesztés céljairól, előnyeiről és szakmai megítéléséről, valamint a kétnyelvi pedagógus számára szükséges kompetenciákról. Feltárulnak az egyének személyes filozófiái a munkavégzéshez kapcsolódó konkrét feladatokról és kihívásokról; a tanítás-tanulás-nevelés-fejlődés folyamatáról, a saját és tanulóik szerepéről, illetve az alkalmazandó módszerekröl, stratégiákról. A nézetek feltárásán és ütköztetésén túl a szimulációk alkalmasak arra is, hogy a résztvevők biztonságos közegben, folyamatos oktatói és csoporttámogatás mellett ki is próbálják, gyakorolják a különböző szituációkat és szerepeket. Az ilyen és hasonló feladatok segítségével mind kommunikációban, vitakészségben, mind a felhasználható elméleti tudásban, a társaiktól kapott ötletekkel, érvekkel megerősödve feltehetően sikeresebben lépnek majd fel valódi élethelyzetekben is. A részletesen is bemutatott metaforarács technika a visszajelzések és az oktatói tapasztalatok alapján is hasznosnak bizonyult. A válaszadói hajlandóság és motiváció magasabb, a feladat egyértelműbb, a metaforaalkotási folyamat gördülékenyebb, mint a hagyományosabb megközelítések esetében. A válaszadás extra magyarázatot, szóbeli kiegészítést, példát, biztatást és pontosítást nem igényelt. A táblázatos forma a hétköznapi kategóriákkal vizuálisan és valóságosan is gyorsabb és egyszerübb feladatmegoldást eredményez, mivel inspirálja a gondolattársítást és egyre több rubrika kitöltésére ösztönöz. Mindezek fényében a metaforarács ajánlható más célfogalmak esetében is a pedagógiai nézetek feltárására. 


\section{Melléklet: A metaforács ${ }^{5}$ (Trentinné Benkő Éva)}

Mi vagy ki lenne az ideális kétnyelvi pedagógus, ha ... lenne?

Írjon egy-egy példát minden kategóriához, és indokolja választását!

\begin{tabular}{|c|c|}
\hline Növény & mert... \\
\hline Állat & mert. \\
\hline $\begin{array}{l}\text { Természeti } \\
\text { jelenség }\end{array}$ & mert... \\
\hline Étel & mert.. \\
\hline Ital & mert... \\
\hline Jármü & mert... \\
\hline Meseszereplö & mert... \\
\hline Használati tárgy & mert... \\
\hline Épület/építmény & mert... \\
\hline Híres ember & mert... \\
\hline
\end{tabular}

\footnotetext{
${ }^{5}$ Első alkalmazás: 2008 KIE-továbbképzésen mühelymunka; helyszín: Budapest, ELTE PPK
} 
Pedagógusnézetek megismerésének lehetőségei a kétnyelvi pedagógusképzés és továbbképzés kontextusában

\title{
2. Melléklet: Példa a hallgatói mesére (a kezdő kétnyelvi pedagógus kalandjairól) és a meséhez fúzött írásbeli reflexióra
}

\author{
Morovik Szabina: Noémi varázslatos kalandja
}

„Hol volt, hol nem volt, volt egyszer egy kislány, akit Noéminek hívtak. Noémi egészen kislánykora óta imádott babázni, legtöbbször azt játszotta, hogy ő az óvó néni, a plüss állatai és a babái pedig a gyerekek. Ahogy telt, múlt az idő, Noémi felcseperedett és láss csodát, arra adta a fejét, hogy igazi óvónő lesz. Tudatosan készült erre, így semmi problémát nem okozott számára az iskola elvégzése. Nagyon örült annak, hogy a tanulmányai végeztével végre elmondhatta magáról, hogy ő bizony óvó néni. Olyan kivételes szerencséje volt, hogy munkát is egyből talált magának egy közeli magyar-angol óvodában.

Nagyon izgatott volt, hiszen addig mindig figyelte valaki, hogy mindent jól csinál-e, segített neki, mikor szüksége volt, de itt bizony főállású óvó néniként ilyen nem lesz. Éjszaka is alig tudott aludni az izgalomtól Noémi. Eljött a reggel. Úgy indult a nap, ahogy szokott. Noémi felkelt, megmosta az arcát, főzött magának egy bögre kávét, megreggelizett és elkezdett készülődni. Indulás előtt még egyszer belenézett a tükörbe, hogy tökéletesen fest-e s ez után útnak indult. Noémi a város szélén lakott egy nagy kertes házban, amitől egy igen hosszú út vezetett a buszmegállóhoz. Amint ment, mendegélt egy nagyon furcsa érzés kerítette hatalmába. Hirtelen elkezdett izzadni a keze és verejtékezett a homloka is. A gyomrában, mintha pillangók röpködtek volna és a szíve is olyan gyorsan vert, hogy szinte hallani lehetett. Hirtelen nagyon aggasztó gondolatai támadtak.

- Mi lesz, ha nem fognak szeretni? Mi lesz, ha nem tudok válaszolni a kérdéseikre? Mi lesz, ha elrontok valamit és kinevetnek? Mi lesz, ha nem jutnak eszembe az angol szavak? Mi van, ha hamisan éneklek valamit, vagy ha a létrát is görbe vonallal rajzolom? - visszhangzottak a kérdések a fejében. Azzal fogta magát és vissza is fordult, mondván, hogy ő bizony még nem készült fel ilyenekre.

Amint sarkon fordult egy aprócska tündér kezdett repkedni Noémi feje körül. Elöször elhessegette, hiszen azt hitte csak egy szúnyog. A kis tündér kitartó volt, így addig repkedett Noémi szeme előtt, míg észre nem vette. Amint észrevette, szája tátva maradt és az uzsonnája, amit aznapra csomagolt magának, azonnal a földre huppant. Nem hitt a szemének. A meglepetés akkor csak nagyobb lett, mikor a tündér megszólította őt.

- Üdvözöllek Noémi, én Pillike vagyok, a te őrző tündéred. Már születésed óta figyellek és készen állok arra, hogy segítsek neked, amikor szükséged van rá.

Noémi még mindig szoborrá dermedve állt és hallgatta Pillike monológját. Nem tudta, hogy most csak álmodik, vagy valóban megtörténik ez vele. Magához térve ő is megszólalt.

- Örző tündérem? Hogy lehet ez? Még sosem láttalak. Miért pont most jöttél el hozzám?

Pillike kedvesen válaszolt is a kérdéseire:

- Eddig nem volt rám szükséged, vagyis, csak nagyon apró dolgokban segítettelek úgy, hogy észre sem vettél. Most viszont úgy éreztem, komoly szükséged van rám.

- De hát miben tudnál te nekem segíteni? A problémáimat csak saját magam oldhatom meg. - felelte Noémi.

- Ez való igaz, - mondta Pillike - éppen ezért vagyok én itt. Nem a megoldást kínálom fel neked, hanem a lehetőséget, hogy magadon segíts.

Azzal suhintott hármat a varázspálcájával és elvarázsolta Noémit egy varázserdőbe. Itt három próbát kellett kiállnia. Nyomban el is indultak az erdő belsejébe. Útjuk során először egy kismadárral találkoztak. Egy gyönyörü szép kismadár, aki narancssárga, lila, zöld, kék és citromsárga színekben pompázott. Furcsa mód nem a társaival röpdösött, hanem egyedül ácsorgott egy bokor árnyékában és szomorkodott.

- Miért búslakodsz kismadár? - kérdezte Noémi.- Te miért nem énekelsz a többiekkel?

- Mert nem tudok énekelni. - felelte szomorúan a kismadár.

Noémi nagyon meglepődött. Ki hallott már ilyet, hogy egy madár nem tud énekelni? Egyből el is kezdett gondolkodni, hogyan tudna neki segíteni.

- Ne szomorkodj kismadár! Van egy nagyon szép kis nóta a tarsolyomban, megtanítom neked! Azzal elkezdte énekelni a nótát. A kismadár érdeklődve hallgatta. Noémi hangjától egy pillanatra megállt az idő az erdőben és minden állat és növény őt hallgatta. Mikor Noémi harmadjára énekelte, a kismadár is bekapcsolódott. Láss csodát! A kismadárnak gyönyörü hangja volt, szebb, mint az összes többi madárnak együtt.

- No, látod kismadár, te is tudsz énekelni, nem is akárhogyan. - mondta Noémi. 
A kismadár azt se tudta hova legyen örömében, hogy végre ő is csatlakozhat társaihoz. Megköszönte Noéminek a segítséget, s már röpült is dalolni a többiekkel.

Tovább mentek, mendegéltek. Ahogy még inkább befelé haladtak egy morcos törpe állta útjukat.

- Kedves kis törpe, kérlek, engedj tovább minket az úton. - kérlelte Noémi, de a törpe megmakacsolva magát válaszolt:

- Én biz, nem engedlek! Ez itt az én utam! Nem használhatja senki sem, ha csak nem ad cserébe valamit.

Noémi nagyon meglepődött, hogy miért ilyen mogorva ez a törpe, s megkérdezte.

- Beléd meg mi ütött kis törpe? Miért vagy ilyen goromba? Mi nem bántottunk, csak a segítségedet kértük, hogy engedj tovább minket. - felelte Noémi.

- Már miért engednélek? Mi hasznom nekem abból? Semmin sem változtatna, ha kedves lennék veletek.

- válaszolta morcosan a törpe.

- Mi nagyon hálásak lennénk neked és segítenél nekünk. Ez nem elég? Jót tehetnél velünk - mondta Noémi.

- Hogy elég-e? Nem elég! Én attól nem leszek boldogabb.

- Nem szeretnél talán két új barátot szerezni? - kérdezte Noémi.

A törpén látszott, hogy megszeppent kicsit és elkezdett gondolkodni. Noémi rájött, hogy miért is ilyen goromba ez a törpe. Neki bizony nincsenek barátai, így nem is tudhatja mit jelent ez. Noémi tovább folytatta:

- Jól gondolom, hogy nincsenek barátaid, igaz? Mi lenne, ha megpróbálnál kicsit kedvesebb lenni mindenkivel és nem valamiért cserébe segíteni? Én a helyedben biztos tennék egy próbát.

A törpe az orra alatt motyogva mondta:

- Hát legyen! Menjetek.

Noémi nagyon hálás volt neki és köszönetképp egy puszit nyomott a törpe feje búbjára. A törpe teljesen belepirult és elmosolyodott. Bizony ez volt az első alkalom, hogy a morcos törpe szája végre nem lefelé görbült. Megfogadta, hogy vége a duzzogásnak és attól a naptól fogva kedves és barátságos törpe lesz. Így is lett, azóta is minden nappal egyre több barátra tesz szert.

Ezen az akadályon is túljutva tovább haladtak Pillikével. Pillike megszólalt:

- Eddig nagyon jól teljesítettél, már csak egy próba van hátra.

Azzal egy hatalmas, terebélyes lombú fához értek. Olyan hatalmas volt a bozontja, hogy még sose látott ilyet addig Noémi. Az erdő egy egész szeletét teljesen eltakarta a nap elöl. Noémi látta, hogy ez a fa csöppet sem boldog attól, hogy ilyen nagyra nőtt.

- Szegény fa! - sóhajtotta. Tehetek érted valamit? Segíthetek valahogy? Mondd, csak mit tehetek érted - kérdezte Noémi.

Előbújt ekkor egy borz az egyik bokor aljából és elkezdte:

- Mi is kérdeztük már, hogy mi baja van, de csak össze-vissza beszél mindenféle halandzsákat. Nem érti senki sem, mit beszél. Az öreg és bölcs bagoly annyit tudott kivenni a szavaiból, hogy valami [kátot] akar, de hát nem tudjuk mi ki az, vagy hol terem.

Noémi elmosolyodott és rájött, hogy ez a fa nem badarságokat beszél, csak egy másik nyelven, s így szólt hozzá:

- Can I help you? Can I do anything for you?

A fa meglepődött, hogy végre valaki úgy szól hozzá, hogy ő is érti. Nehézkesen felelte:

- Cut some of my limbs off, please. They are so heavy.

Noémi megértette, amit eddig senki sem. Egy kis ritkításra szorult szegény fa, csakhogy akkora volt, hogy Noémi egyedül aligha tudott volna segíteni, ezért kérte Pillike segítségét, aki egy gyors varázslattal megszabadította a fát a felesleges ágaktól. A fa nagyon megörült és megkönnyebbült.

- Thank you my friends!

Azzal hirtelen Pillike visszavarázsolta az útra Noémit.

- Máris vége? Hisz el se tudtam köszönni tőlük. - mondta Noémi.

Pillike így szólt:

- Kiálltad mind a három próbát. Már nem kell félned, hogy nem állod meg a helyed a gyerekek között.

- Miben segíthetne nekem ez bármiben is? Nem is találkoztam gyerekekkel. - kérdezte meglepődve Noémi.

- Nos, lássuk csak! - válaszolt Pillike. Segítettél egy kismadárnak megtalálni a hangját, így már vidáman dalolhat a társaival. Ezután segítettél egy társaitól elszakadt törpének újra beilleszkedni a társai közé azzal, hogy megmutattad neki a kedvesség és a barátság erejét. Végül pedig, csak te tudtál segíteni azon a fán, aki nem ugyanazt a nyelvet beszélte, amit mindenki más.

Noémi figyelmesen hallgatva Pillikét rájött arra, hogy igaza van, így elhatározta, hogy bátor lesz 
Pedagógusnézetek megismerésének lehetőségei a kétnyelvi pedagógusképzés és továbbképzés kontextusában

és gyorsan eléri a városba tartó buszt. Így is lett. Egész úton a varázslatos erdő járt az eszében. Biztos volt abban, hogy ezt a kalandot sosem fogja elfelejteni. Mikor megérkezett az óvodába, a gyerekek mind barátságosan fogadták. Gyorsan sikerült megtanulnia az összes gyermek nevét és jelét is. Igazán vidám napot töltöttek együtt.

Mikor aztán az összes gyermeket hazavitték a szüleik, Noémi is hazatért. Fáradtan az ágyba heveredve ismét megjelent neki Pillike. Noémi nagyon hálálkodott neki, hogy segített bátorságot gyüjteni és megmutatni neki, hogy mi mindenre képes is ő valójában. Pillike megígérte Noéminek, hogy rendszeresen meglátogatja és mindig ott lesz neki, ha szüksége lesz rá. A búcsú után hamar álomköd borult Noémi szemére és álmában újra találkozhatott a varázslatos erdő lakóival."

Morovik Szabina: Reflexió a meséről

„Amesém egy kétnyelvű óvodapedagógus, Noémi félelmeiről szól. Tart attól, hogy miként fog beilleszkedni a gyerekek közé. Noémi félelmei az én félelmeim is, sőt talán mondható, hogy általánosságban egy óvodapedagógusnak készülő ember félelmei. Nem is pont ez a jó szó, hogy félelem, de olyan dolgok, melyek az elején nehézséget jelenthetnek majd számunkra. Melyikünknek ne jutna eszébe az, hogy mi lesz akkor, ha egy kisgyermek nem fogad el minket, nem szeret, nem fogad szót nekünk? Titkon mindannyian küzdünk azzal, hogy az óvodában valamilyen formában „produkálnunk” kell majd magunkat, legyen ez egy dal eléneklése, bábozás vagy esetleg eljátszani egy dramatikus mesét. Ezekkel próbálunk ismerkedni tanulmányaink során és barátságot is kötni, hogy ne legyen olyan nehéz dolgunk leendő óvodapedagógusként. A mesém természetesen úgy ér véget, hogy Noémi leküzdi a félelmeit és nem riad meg a feladattól, saját maga tapasztalja meg azt, hogy az esetleges problémának megélt helyzeteket tudja kezelni a saját erejéböl. Természetesen a mesémben felsorolt félelmeink leküzdése mellett a módszertani tudás is létfontosságú alapköve a kétnyelvű óvodai nevelésnek. Hiszem azt, hogy mindannyiunknak ebben kell hinnünk, hiszen ott már senki nem fogja a kezünket fogni és istápolni, hogy mit hogyan kell csinálnunk. Ott már nem lesz helye bizonytalankodásnak, ezért biztosnak kell lennünk saját magunkban és a képességeinkben is, valamint hinnünk kell, hogy nem véletlenül válogattak be minket az egyetemre és remélhetöleg 3 év elteltével jogosan nevezhetjük magunkat ugyan még csak gyakorló, de hivatásos óvodapedagógusnak."

\section{Felhasznált irodalom}

Adam, S. (2004): Using Learning Outcomes: A consideration of the nature, role, application and implications for European education of employing learning outcomes at the local, national and international levels. Report on United Kingdom Bologna Seminar, July 2004. Heriot-Watt University, Edinburgh.

Allan, J. (1996): Learning outcomes in higher education. Studies in Higher Education, 21. 10., 93-108.

Bárdossy lldikó - Dudás Margit (2011): Pedagógiai nézetek. Tanári mesterképzést bevezető tanulási/tanítási program oktatók és hallgatók számára. Pécsi Tudományegyetem, Pécs.

Ben-Peretz, M., Mendelson, N. \& Kron, F. W. (2003): How teachers in different educational contexts view their roles. Teaching and Teacher Education, February, 19. 2., 277-290.

Bullough, R. V. \& Stokes, D. K. (1994): Analyzing Personal Teaching Metaphors in Preservice Teacher Education as a Means for Encouraging Professional Development. American Educational Research Journal, March 20, 31, 197-224.

Calderhead, J. (1996): Teachers: Beliefs and Knowledge. In Berliner, D. - Calfee, R. (eds): Handbook of Educational Psychology. MacMillan, New York. 709-725.

Dudás Margit (2005): A tanárképzésbe belépő hallgatók nézeteinek feltárási lehetőségei. Pedagógusképzés, 3, 23-43.

Dudás Margit (2006): Pedagógusjelöltek belépő nézeteinek feltárása. Pécsi Tudományegyetem BTK Neveléstudományi Intézet, Pécs.

Dudás Margit (2007): Tanárjelöltek belépő nézeteinek feltárása. In Falus Iván (szerk.): $A$ tanárrá válás folyamata. Gondolat Kiadó, Budapest. 46-120.

Ehmann Bea (2002): A szöveg mélyén. Új Mandátum Kiadó, Budapest.

Falus Iván (2001): Pedagógus mesterség - pedagógiai tudás. Iskolakultúra, 2. 21-28. 
Falus Iván (1998, szerk.): Didaktika. Elméleti alapok a tanítás tanulásához. Nemzeti Tankönyvkiadó, Budapest.

Falus Iván (2002) A tanuló tanár. Iskolakultúra, (6-7) 75-80.

Falus Iván (2004): A pedagógussá válás folyamata. EDUCATIO (3) 359-374.

Falus Iván (2006): A tanári tevékenység és a pedagógusképzés új útjai. Gondolat Kiadó, Budapest.

Falus Iván (2007, szerk.): A tanárrá válás folyamata. Gondolat Kiadó, Budapest.

Golnhofer Erzsébet és Nahalka István (2001, szerk.): A pedagógusok pedagógiája. Nemzeti Tankönyvkiadó, Budapest.

Hegyi Ildikó (1996): Siker és kudarc a pedagógus munkájában: a pedagógiai képességek és fejlesztésük módjai. Okker Kiadó, Budapest.

Hunyady Györgyné - Ungárné Komoly Judit (1999): Pedagógusjelöltek nevelési attitűdjeinek vizsgálata irodalmi szemelvények segítségével. In Bollókné Panyik llona (szerk.): Gyermek-nevelés-pedagógusképzés. Trezor Kiadó, Budapest. 7-38.

Hunyady Györgyné (2001): Laikus pedagógiai nézetek vizsgálata. In: Tanulmánykötet. NyME Apáczai Csere János Tanítóképző Főiskolai Kar, 62-71.

Hunyady Györgyné (2004): Laikus pedagógiai tapasztalatok és nézetek vizsgálata a tanítójelöltek körében. In BollóknéPanyik llona (szerk.): Gyermek-nevelés-pedagógusképzés. Az ELTE TÓFK Tudományos Közleményei XXVII. Trezor Kiadó, Budapest. 9-33.

Hunyady Györgyné (2006): Pedagogikum a szépirodalomban. In M. Nádasi Mária (szerk.): A gyakorlati pedagógia néhány alapkérdése: Pedagogikum a hétköznapokban és a müvészetekben. Bölcsész Konzorcium, Budapest. 15-36.

Kimmel Magdolna (2007): A tanárképzés problémái konstruktivista értelmezési keretben. In Falus Iván (szerk.): A tanárrá válás folyamata. Gondolat Kiadó, Budapest. 11-45.

Korthagen, F. A. J. (1993): Two modes of reflection. Teaching and Teacher Education, (9) 3, 317-326.

Kövecses Zoltán (1998): A metafora a kognitív nyelvészetben. In: Pléh Csaba és Győri Miklós (szerk.): A kognitív szemlélet és a nyelv kutatása. Pólya Kiadó, Budapest. 50-82.

Kövecses Zoltán (2005): A metafora. Gyakorlati bevezetés a kognitív metaforaelméletbe. Typotex Kiadó, Budapest

Lakoff, G. \& Johnson, M. (2003): Metaphors We Live By. The University of Chicago Press, London.

Mason, Jennifer (2005): Kvalitatív kutatás. Jószöveg Kiadó, Budapest.

M. Nádasi Mária (1999): Hétköznapi és/vagy tudományos pedagógia? Tanári létkérdések. Raabe Kiadó, Budapest.

M. Nádasi Mária (2001): A pedagógus pálya foglalkozási ártalmai - pályakezdők közérzete. In Radnainé Szendrei Julianna (szerk.): Ezredforduló, müveltségkép, kisgyermekkori nevelés. Trezor Kiadó, Budapest. 70-74.

M. Nádasi Mária (2002): Az oktatáselméletek hatás(talanság)a a gyakorlatra. In Bábosik István - Kárpáti Andrea (szerk.): Összehasonlító pedagógia. Books in Print Kiadó, Budapest. 201-213.

M. Nádasi Mária (2006): Pedagogikum a hétköznapokban. In M. Nádasi M. (szerk.): A gyakorlati pedagógia néhány alapkérdése: Pedagogikum a hétköznapokban és a müvészetekben. Bölcsész Konzorcium, Budapest. 4-14.

Pittman, K. \& O'Neill, L. (2001): Using metaphors to Evaluate Ourselves. Classroom Leadership, Evaluating Educators, February, 4. Number 5.

Réthy Endréné (2001): Motivációs elképzelések. In: Golnhofer Erzsébet - Nahalka István (szerk.): A pedagógusok pedagógiája. Nemzeti Tankönyvkiadó, Budapest. 177-200.

Richardson, V. (1996): The role of attitudes and beliefs in learning to teach. In Sikula, J. (ed.): Handbook of Research on Teacher Education. Macmillan, New York. 102-119.

Sallai Éva (1994): A pedagógusmesterség tartalma és tanulhatósága, különös tekintettel a pedagógusszemélyiség kialakulására. Bölcsészdoktori disszertáció. ELTE, Budapest.

Sallai Éva (1996): Tanulható-e a pedagógusmesterség? Veszprémi Egyetemi Kiadó, Veszprém. 
Pedagógusnézetek megismerésének lehetőségei a kétnyelvi pedagógusképzés és továbbképzés kontextusában

Sántha Kálmán (2004): A pedagógusok reflektív gondolkodásának vizsgálata. Pedagógusképzés, 2, 27-44.

Sántha Kálmán (2006): Mintavétel a kvalitatív pedagógiai kutatásban. Kutatás-módszertani kiskönyvtár, Gondolat Kiadó, Budapest.

Seidman, I. (2002): Az interjú, mint kvalitatív kutatási módszer. Kutatás-módszertani kiskönyvtár, Müszaki Könyvkiadó, Budapest.

Szabolcs Éva (1999): A kvalitatív kutatási módszerek megjelenése a pedagógiában. In Magyar Pedagógia, 3, 343-348.

Szabolcs Éva (2001): Kvalitatív kutatási metodológia a pedagógiában. Műszaki Könyvkiadó, Budapest.

Szivák Judit (2002): A pedagógusok gondolkodásának kutatási módszerei. Müszaki Könyvkiadó, Budapest.

Szivák Judit (2003a): A reflektív gondolkodás fejlesztése. Gondolat Kiadói Kör, ELTE BTK Neveléstudományi Intézet, Budapest.

Szivák Judit (2003b): Hallgatók neveléssel kapcsolatos nézetei. Iskolakultúra, 5, 88-95.

Trentinné Benkő Éva (2008): Az „ideális” kéttannyelvű tanár - ahogy a pedagógusok látják. In: Vámos Ágnes - Kovács Judit (szerk.): A két tanítási nyelvü oktatás elmélete és gyakorlata 2008-ban. Jubileumi tanulmánykötet. Eötvös József Könyvkiadó, Budapest. 248-264.

Trentinné Benkő Éva (2009): Az „ideális” kéttannyelvű tanár - ahogy a pedagógusok látják. In: Kovács Judit - Márkus Éva (szerk.): Kéttannyelvüség - Pedagógusképzés, kutatás, oktatás. ELTE Eötvös Kiadó, Budapest. 143-158.

Trentinné Benkő Éva (2013a): A kétnyelvi pedagógusképzésbe belépő hallgatók nézetei és motivációi. In: Árva Valéria - Márkus Éva (szerk.): Az ELTE TÓK Idegen Nyelvi és Irodalmi Tanszékének Tudományos Közleményei. Education and/und Forschung II. ELTE TÓK, Budapest. 251-276.

Trentinné Benkő Éva (2013b): Kétnyelvi pedagógusképzésben részt vevő hallgatók nézeteinek megjelenése kreatív vizuális alkotásaikban. Gyermeknevelés 1. 1. sz., 73-106.

Trentinné Benkő Éva (2014): Meseelemzés a korai idegen nyelvi fejlesztéssel kapcsolatos pedagógusnézetek, kompetenciák, tanulási eredmények feltárására. In: Márkus Éva és Trentinné Benkő Éva (szerk.): A korai idegen nyelvi fejlesztés elmélete és gyakorlata. ELTE Eötvös Kiadó, Budapest, 390-411.

Trentinné Benkő Éva (2015a): Tanulási eredmények értékelése a korai kétnyelvű fejlesztésre felkészítő pedagógusképzésben. Neveléstudomány. 3. 2. sz., 30-62

Trentinné, Benkő Éva (2015b): Teacher Training for CLIL in Hungary: An empirical research. In: Hanesová, Dana (ed.): Learning Together To Be a Better CLIL Teacher. Proceedings from International Conference. Univerzita Mateja Bela, Banská Bystrica, 29-38.

Vámos Ágnes (2001a): Iskolai értékelés fogalmának elemzése metaforahálóval. In Golnhofer Erzsébet - Nahalka István (szerk.): A pedagógusok pedagógiája. Nemzeti Tankönyvkiadó, Budapest. 283-306.

Vámos Ágnes (2001b): Metafora felhasználása a pedagógiai fogalmak tartalmának vizsgálatában. Magyar Pedagógia, 1, 85-114.

Vámos Ágnes (2002): Tanárképek a csalédban. In: A tudásalapú társadalom pedagógiája. II. Országos Neveléstudományi Konferencia, Budapest.

Vámos Ágnes (2003a): Metafora a pedagógiában. Gondolat Kiadói Kör, ELTE BTK Neveléstudományi Intézet, Budapest.

Vámos Ágnes (2003b): Metafora a pedagógiai kutatásban. Iskolakultúra, 4, 109-112.

Vámos Ágnes (2008): A kezdő tanár mint hős: a mese és pedagógiai felhasználása. Iskolakultúra, 1-2, 24-38.

Vámos Ágnes (2011) A tanulási eredmények alkalmazása a felsőoktatási intézményekben 2. Bologna füzetek 6 . Tempus Közalapítvány, Budapest.

Wubbels, T. (1992): Taking account of student teachers' preconceptions. Teaching and Teacher Education, 8 (2), 137-149. 